\title{
Between Language Revitalization and Assimilation: On the Language Situation of the German Minority in the Czech Republic
}

\author{
Sandra Kreisslová' and Lukáš Novotný \\ 'Czech University of Life Sciences Prague \\ ${ }^{2}$ Czech Technological University in Prague
}

\begin{abstract}
Language preservation is considered to be one of the central missions of ethnic groups. For the German minority in the Czech Republic too, language plays an important role in group identity. Its current language situation is a result of the negative historic developments after World War II and under the communist regime. Due to the forced resettlement of most German-speaking inhabitants and the subsequent assimilation policies of the communist regime, the German community underwent strong cultural and language assimilation, which is also attested by the steady decline of its membership. The study focuses on issues of the language situation of the German minority and the revitalization efforts that have been undertaken by its elite in cooperation with other relevant institutions. A research survey of the main representatives of the minority and its regional associations demonstrates their evaluations of the ways in which German language is currently used and promoted in the Czech Republic, and it also points to the different strategies they have been striving to implement to reverse the language shift.
\end{abstract}

\section{Keywords}

German minority; Czech Republic; language situation; language shift; language assimilation; language revitalization

\section{Introduction}

Language is typically considered the central attribute of ethnic identity (Spolsky 1998; Šatava 2009) and may play important self-identifying and ethnodifferentiating roles for ethnic minorities. However, during their contact with dominant languages of their countries, minority languages tend to be under strong social and political pressure, which may result in a language shift from the original language used in everyday communication to another (dominant) language (Weinreich 1968: 106). These tendencies

\footnotetext{
* Sandra Kreisslová, Czech University of Life Sciences Prague, Faculty of Economics and Management; Kamýcká 129, 16521 Prague 6; kreisslova@pef.czu.cz;

Lukáš Novotný (corresponding author), Czech Technological University in Prague, MIAS School of Business, Kolejní 2a, 16000 Prague 6; novotny.l@centrum.cz.
} 
can also be observed for the German minority in the Czech Republic, whose current language situation is a result of the negative historic developments after World War II (WWII) and under the communist regime. Due to the forced resettlement of most German-speaking inhabitants and the subsequent assimilation policies of the communist regime (also refer Staněk 1993; Spurný 2011), which were centered on language issues, the German community underwent strong cultural and language assimilation. This is also attested by a steady decline of its membership: from 159,938 individuals who identified with the German nationality in 1950 , the community shrank to 18,658 individuals according to the most recent census in 2011. Germans are thus less numerous than most of the other 14 officially acknowledged national minorities in the Czech Republic. However, this weakness in numbers does not correspond with the economic power of the German state as well as the latter's general commitment and ability to support German minorities in Central and Eastern Europe. Both the Czech government and the Federal Republic of Germany are currently implementing their language policies and certain instruments to preserve German as a minority language. Financial aid and other support from the German state is crucial for the minority; it is channeled primarily through the Federal Ministry of Interior, but also through cultural and educational institutions such as the Goethe-Institut. Germany's pledge was last renewed in September 2017, when Hartmut Koschyk, Commissioner of the Federal Government for the issues of immigrants and ethnic minorities, visited Prague and negotiated about the support (Aussiedlerbeauftragter 2017).

The present study focuses on the linguistic situation of the German minority. The primary aim of the paper is to discuss the necessity of revitalizing the German language in the Czech Republic. Secondarily, we seek to define strategies that might be used to revitalize German as a mother tongue. Although representatives of the German minority often deal with this issue, it has not been described or studied academically thus far. In the following discussion, we build on our previous investigations on the situation of the German minority after 1989 (especially Kreisslová/Novotný 2015), as well as the unstructured interviews with the main representatives of the Assembly of German Associations in the Czech Republic (we conducted three interviews with members of the former and current leadership of the Assembly, focusing on the minority's cultural, political, and linguistic activities) and a short questionnaire distributed in 2017 to representatives of the 22 regional associations that exist under that umbrella (these associations correspond with the territorial distribution of the German minority in the country). The questionnaire focused on opinions about the German minority's linguistic situation in the different regions, thus assuming an emic perspective on the 
subject matter. Furthermore, we conducted participant observation at two of the Assembly's events: the Großveranstaltung (Great Cultural Gathering) and a related conference on the current state of the minority in the Czech Republic (2014); and the annual Herbsttagung (Autumn Meeting) of representatives of the German minority in 2017.

\section{Theoretical background}

Efforts of national minorities typically focus on preservation of language and cultural activities (McDermott 2016; Sandovici/Listhaug 2009; Fairclough 2003; Togeby 2008). While language is not always a necessary trait of national/ ethnic identity, it is indeed a dominant characteristic in the European context (Šatava 2009: 37). Through the lens of the language ecology paradigm, on which the present paper relies, language is viewed as part of ethnic groups' cultural capital, and linguistic diversity is considered beneficial. Accordingly, contemporary states should stand up against the pressure of globalization and confront the process of assimilation of minority and regional languages (Nekvapil 2010). The European Union strives to support and preserve them under the framework idea of "unity in diversity" (European Parliament 2017), and the Council of Europe has adopted the European Charter for Regional or Minority Languages in 1992 (German in the Czech Republic has been covered since 2007). The different countries' policies toward national minorities also address these issues (Šatava 2009; Neustupný 2002). The language interests of the German minority in the Czech Republic are provided for in the constitution (Chapter 3, Article 25 (2) (a) of the Charter of Fundamental Rights and Freedoms), as implemented by Act No. 273/2001 Coll., on the Rights of Members of National Minorities (Petráš 2007).

The rights of national minorities in the Czech Republic include the right to use one's name and surname in the minority's language, the right to multilingual names and denominations, the right to use the minority's language during contact with the authorities and before courts, the right to use that language in electoral matters and in schooling, and the right to disseminate and receive information in that language (for more details, refer Dovalil 2013: 13-30). Those rights are also recognized by various educational institutions and nongovernmental organizations (NGOs), which exist mostly at the regional level in the case of the German minority (e.g., the Tandem - Czech-German Youth Exchange Coordination Centre). Crucial for the minority is aid from the Federal Republic of Germany, which is provided by the German Ministry of the Interior (BMI) through the German Embassy in Prague, as well as by cultural institutions such as the Institute for Foreign Cultural Relations at Goethe-Institut, various other foundations, Sudeten Germans, and other 
associations. Last but not the least, the Czech-German Fund for the Future is a key intergovernmental organization that supports the minority's projects (Novotný 2015b: 138).

Previous empirical studies (cf. Kreisslová 2013, Kreisslová/Novotný 2015) suggest that for the German minority in the Czech Republic too, language plays an important role in group identity. A German identity is constructed primarily by the oldest generation of Czech Germans who were born before 1945 and stayed in Czechoslovakia after the war, relying primarily (although not exclusively) on German dialects that are seen by their speakers as their mother tongue. The second (born after 1945) and third (born after 1981) generations are more inclined toward a Czech identity and the Czech language, or toward dual identities and bilingualism (symmetrical or asymmetrical and passive bilingualism can be observed). It is characteristic of the current development of the national minority in question that German language skills at the level of the mother tongue are gradually vanishing. As mentioned above, this language shift is taking place in the context of assimilation or integration processes. It has been corroborated at the level of linguistics (Neustupný/Nekvapil 2003), psychology, society, and politics (Kuklík/Petráš 2017; Houžvička 2015), and it is supported by a number of historic arguments (Staněk 1993). After the year 1989 , this language community has seen an effort to preserve its language, on the one hand, and ameliorate a cultural-language stagnation on the other hand. The extent to which a language is threatened can be determined using the Language Vitality and Endangerment (LVE) model created by the United Nations Educational, Scientific and Cultural Organization (UNESCO) (Moseley 2010) (Table 1).

Table 1: Intergenerational language transmission

\begin{tabular}{|c|c|c|}
\hline Degree of endangerment & Grade & Speaker population \\
\hline Safe & 5 & $\begin{array}{l}\text { The language is used by people } \\
\text { of all ages, from children up. }\end{array}$ \\
\hline Unsafe & 4 & $\begin{array}{l}\text { The language is used by some chil- } \\
\text { dren in all domains; it is used by } \\
\text { all children in limited domains. }\end{array}$ \\
\hline Definitively endangered & 3 & $\begin{array}{l}\text { The language is used mostly by } \\
\text { the parental generation and up. }\end{array}$ \\
\hline Severely endangered & 2 & $\begin{array}{l}\text { The language is used mostly by the } \\
\text { grandparental generation and up. }\end{array}$ \\
\hline Critically endangered & 1 & $\begin{array}{l}\text { The language is used mostly by } \\
\text { very few speakers, of the great- } \\
\text { grandparental generation. }\end{array}$ \\
\hline Extinct & 0 & There exists no speaker. \\
\hline
\end{tabular}

Source: UNESCO (2003: 8). 
Interruption in the chain of intergenerational transmission of language is the central criterion in this model. A language is considered safe if spoken by all generations, a sign that intergenerational transmission operates uninterrupted. On the other extreme, the language is extinct when the last speaker has been lost. German as a minority language in the Czech Republic can be categorized as severely endangered (Grade 2) as it is only used by the oldest generation anymore. From this perspective, the ethnic group in question is considered to be an endangered language community.

An alternative model was created by Joshua Fishman (1991: 88-90). Inspired by the Richter scale of earthquake strength, his Graded Intergenerational Disruption Scale (GIDS) determines the level of language shift for minority languages using eight stages:

Stage 8: Most vestigial Xish users are socially isolated and Xish needs to be reassembled from their mouths and memories and taught to demographically unconcentrated adults.

Stage 7: Most Xish users are a socially integrated and ethnolinguistically active population but are beyond child-bearing age.

Stage 6: The attainment of intergenerational informal oracy and its demographic concentration and institutional reinforcement.

Stage 5: Xish literacy in the home, school, and community, but without taking on extracommunal reinforcement of such literacy.

Stage 4: Xish in lower education that meets the requirements of compulsory education laws.

Stage 3: Use of Xish in the lower work sphere (outside the Xish neighborhoodl community) involving interaction between Xmen and Ymen.

Stage 2: Xish in lower governmental services and mass media but not in higher spheres of either.

Stage 1: Some use of Xish in higher-level educational, occupational, and media efforts (but without the additional safety provided by political independence).

Applying this model to Germans in the Czech Republic, the current state of German language and its dialects as mother tongues of this community can be classified as Stage 7. Most speakers come from the oldest generation but, as opposed to Stage 8, they are not isolated. In fact, they are socially integrated, in contact with their children, grandchildren, and other people of the same cultural background. Although their mother tongue differs from the dominant language, they are integrated into the majority society. To revitalize such a strongly affected language, Fishman recommends documenting and reconstructing the language as much as possible. Furthermore, he calls - and we share his appeal as perhaps fundamental for the needs of the community 
in question - on the second generation to adopt the language as its "second language" so that it can be subsequently passed on to their children as their first or second language. In this way, an active language community would arise, with older generations supporting younger ones. It is apparent that the effort to preserve the group's ethnolinguistic specifics depends, first and foremost, on the community itself, its acknowledgment of their value, and its effort to convince its very members - so that intergenerational transmission of language can reemerge. As noted by sociolinguist Glyn Williams (2007: 168), among others, language revitalization cannot rely exclusively on the family environment - the economy plays a fundamental role as well. Not only minority language speakers and their descendants, but also the general public, should believe in the importance of bi- or multilingualism so that most people agree about the positive effects and economic potential of mastering several languages. Promotion of the minority language should take place both bottom-up, at the initiative of the minority itself, and top-down, with the support of various NGOs, businesses, schools, and the government.

\section{The German minority and the German language}

Postwar stigmatization and segregation of the German language and culture in Czechoslovakia, followed by the assimilation policies of the communist regime, led to exclusion of the German language from public life. It was only in the year 1968, through Constitutional Act No. 144/1968 Coll., that the German population was granted minority rights, including the right to education in one's mother tongue (cf. Kuklík/Petráš 2017). However, schools with German as the language of instruction were eventually not established, a fact with fundamental consequences for subsequent generations' knowledge of German. At this time, the mother tongue of Czechoslovak Germans was little useful and enjoyed little respect outside the ethnic group. As the language shift took place over several decades, most members of the language community became monolingual or learned German as a foreign language at school (the latter only to a limited extent before 1989).

The different generations of the German minority exhibit different levels of language skills. The oldest generation grew up before and during WWII, when the German language dominated all walks of social life. German, often in the form of local dialects, was a central part of the ethnolinguistic identity of these people. The level of knowledge of standard German in this oldest generation of Czech Germans depends on their year of birth. Individuals born before 1938 went to German schools and, as a rule, exhibit a good level of standard German; knowledge of Czech may be limited. (Knowledge 
of Czech before 1945 depended, for example, on the extent of the person's contacts with the Czech population or whether one sought to work for the government - according to the Language Regulation of 1926, all civil servants had to pass examinations in the official language, i.e. Czech. After the end of WWII, Germans were subject to a strong assimilation pressure; however, extremely old individuals or homemakers, among others, were not forced to learn Czech.) Individuals born between 1939 and 1945 were exposed to the dominant German language environment in their childhood, and thus German still plays an important role in their ethnic identity. In contrast to the older cohorts, these individuals attended Czech or Slovak schools and did not have access to formal instruction of their mother tongue during the communist era (or such instruction was limited to so-called language circles; refer Staněk 1993). German language skills weakened due to the absence of communication domains, which were practically limited to the intimate sphere of family life. In contrast, the Czech educational system guaranteed their relatively decent mastering of the dominant language (Kreisslovál Novotný 2015: 123; Novotný 2015a: 26).

As an illustration of the language situation of the post- 1945 generation, studies from the 1950s found declining knowledge of standard German among children from ethnically mixed families and beyond. Studies from the $1960 \mathrm{~s}$ demonstrate that $75 \%$ of partners in interethnic marriages and $68 \%$ of their children spoke Czech only (Staněk 1993: 147). This evidence suggests that intergenerational transfer of a German ethnolinguistic identity no longer took place in interethnic families. They gave up passing on the German language and prioritized raising their children in the dominant language to facilitate their adaptation to the social environment.

Isolated exceptions aside, the youngest generations born after 1981 exhibit almost complete language assimilation, shifting from bilingualism to Czech monolingualism, which can be substantiated both by census evidence on self-declared mother tongue (refer Table 2) and by scholarly investigations (Kreisslová/Novotný 2015). The social and political transformation after 1989 made room for more liberal language planning (for more details, refer Neustupný/Nekvapil 2003; Nekvapil/Nekula 2006) and brought the German language back to school curricula. As a result, some members of the youngest generation learned German as their second language, as opposed to the older generations having German as their mother tongue. Individuals who learned German in foreign language courses mastered various levels of language skills. In families wherein intergenerational transfer of the German language continued under the communist regime, despite assimilation 
pressures, members of the youngest generation are likely to use standard German nowadays, which gives them more opportunities.

Attitudes to German as one's mother language were also covered by some censuses. The most recent census of 2011 defined mother tongue as that spoken to the person during childhood by their mother or people raising them. The census of 2001 found that more people declared German as their mother tongue $(41,238)$ than identified themselves as of German nationality $(39,106)$, whereas the trend reversed 10 years later, with 18,658 individuals declaring German nationality and 14,148 declaring German as their mother tongue (Table 2). One-fourth of self-declared ethnic Germans stated Czech as their mother tongue, and 26,642 people stated a combination of the German and Czech languages.

Table 2: Differences between nationality and mother tongue in the German minority, 2001 and 2011

\begin{tabular}{|l|l|l|}
\hline \multirow{2}{*}{} & Census \\
\cline { 2 - 3 } & $\mathbf{2 0 0 1}$ & $\mathbf{2 0 1 1}$ \\
\hline Nationality & 39,106 & 18,658 \\
\hline Difference & 41,238 & 14,148 \\
\hline 2011/2001 index & $-2,132$ & 4,510 \\
\hline Mother tongue-to-nationality ratio & n/a & 47.7 \\
\hline
\end{tabular}

Source: Czech Statistical Office (ČSÚ 2014: 21).

\section{Promotion of the German language}

As mentioned earlier, the right to education in one's mother tongue is guaranteed to members of national minorities by the Charter of Fundamental Rights and Freedoms and Act No. 273/2001 Coll., on the Rights of Members of National Minorities, according to which "members of national minorities living traditionally and for a long time on the territory of the Czech Republic have right to use the language of a national minority in official documentation and discourse and hearing before a court. Conditions for exercise of this right are determined in special legal regulations." Furthermore, Act No. 561/2004 Coll. on Pre-school, Basic, Secondary, Tertiary Professional and Other Education (the Education Act) defines in Section 14 certain conditions for setting up schools in a national minority's mother tongue. A class of primary school with a national minority's mother tongue as language of instruction shall be opened if at least 10 such minority pupils enroll. At least 12 students must enroll for a class of secondary school to open. To establish a school with a national minority's mother tongue as language of instruction, 
every class shall have at least 12 minority pupils for primary schools and at least 15 minority students for secondary schools. However, meeting these conditions continues to be difficult for the German minority, considering the strong degree of assimilation and territorial dispersion, which is also a result of internal displacement after WWII (see also Dvořák 2013). The Assembly of Germans was formed in the 1990s, subsequently renamed as Assembly of Germans in Bohemia, Moravia, and Silesia (Shromáždění Němců $v$ Čechách, na Moravě a ve Slezsku), and currently, it is known as the Assembly of German Associations in the Czech Republic (Shromáżdèní némeckých spolkư $v$ České republice, hereinafter referred as the "Assembly"). Ever since the 1990s, representatives of the Assembly have strived to improve the minority's language situation. Its elites are aware of the value and importance of their original mother tongue, a fact confirmed in the interviews (interviews with W. Piverka 2014/Chomutov, R. Šulko 2014/Nečtiny, M. Dzingel 2014, 2017/ Prague). Thus, promotion of the German language and efforts to revitalize it are among the central goals of the Assembly (see Landesversammlung 2012). The early 1990s saw a failed attempt to establish a state school with German as the language of instruction. The Assembly was unable to bring the required minimum number of children of German nationality in accordance with Act No. 564/1990 Coll., on State Administration and Self-Government in the School System. The minority's representatives tried to change the law and use the criterion of interest in the German language instead of nationality, but no amendments have been achieved since then (Kreisslová/Novotný 2015: 129).

As the only positive achievement in this respect, the Association of Germans in the Prague and Central Bohemian Region (Svaz Nèmcù v regionu Praha a středni Čechy) established the private Primary School of German-Czech Understanding (Základni škola némecko-českého porozuméni) in Prague in 1991 (now run by the Assembly). In following up on this school, the Thomas Mann Grammar School (Gymnázium Thomase Manna) was established in 1995. However, considering the tuition fees, the private school is not accessible for all members of the minority, and the same applies to those other private schools not owned by the minority that provide bilingual education. Moreover, the Grammar School is located in Prague, where few members of the German minority reside. In contrast, no bilingual Czech-German school at any educational level has been established by the Assembly in the frontier regions of the country, where most members of the minority have their homes (Kreisslová/Novotný 2015: 130). In these regions, they must attend bilingual institutions not owned by the minority, which proves to be a welcome synergy in some regions such as Liberec (as demonstrated by the survey; refer the following text). 
Nowadays, German is also taught outside the school network, as part of adult education or other institutions. The minority itself strives to implement instruction primarily at social clubs that have been established by the different regional associations of the Assembly since the 1990s. Some of those clubs provide German courses or libraries of German literature. However, their level and quality of performance vary across regions. Moreover, some courses of German have meanwhile been discontinued, e.g., in the North Bohemian city of Chomutov, which is paradoxical, considering the minority's highest concentration in that region. In contrast, the North Moravian association has been highly active, with a long tradition of intensive German conversation courses for children and youth of German descent (interview with M. Dzingel 2014/Prague). The same association has been also organizing language exchange since the 1990s, both domestically and abroad, and has been involved in various activities with the German Institute for Foreign Cultural Relations (including international summer camps) and the GoetheInstitut (for more details, see Kreisslová/Novotný 2015: 131). More generally, Goethe-Institut has been a partner in educating German teachers and promoting German both among German minority members and in the majority population. Some of the associations also make use of the cultural programs offered. Again, although Goethe-Institut is primarily active in Prague, we would consider it appropriate for its coverage to extend to other regions. The campaign entitled, Šprechtime, is the latest project undertaken by the Goethe-Institut in collaboration with the German and Austrian embassies, the Central Agency for German Schools Abroad, the Austrian Cultural Forum in Prague, Österreich Institut Brno, the business section of the Austrian Embassy in Prague, and the Czech-German Chamber of Commerce and Industry. It aims at promoting German and increasing its prestige by emphasizing the economic and cultural advantages of speaking the language in the Czech context. It responds to the Czech Republic's economic integration with Germany and demonstrates the benefits of bilingualism in professional life (Goethe-Institut 2016). After 1989, new job positions opened in German companies, commerce, and tourism, contributing to the demand for knowledge of standard German. This poses a great potential for revitalization of German as a minority language (Kreisslová 2018: 66).

The media plays a fundamental role in the vitality of a language. Access to German-speaking mass media from abroad is practically unlimited nowadays, compared to the pre-1989 era. The law prescribes the Czech public radio to broadcast programs for minorities, but this plays a marginal role in practice. In this regard, the German minority is involved in publishing its own press, although there has been some stagnation recently. The Assembly used to 
publish two newspapers (Landeszeitung and Prager Volkszeitung) but now only publishes the LandesEcho monthly. Thus, the minority no longer has its own newspaper (for more details, see Kreisslová/Novotný 2015: 135-149; Novotný 2016: 148).

The empirical study makes it clear that representatives of the German minority in Prague are exerting considerable effort to preserve and develop the German language because they consider its existence as key to preserving the group's ethnic specifics. They are also striving to disseminate these ideas and activities in support of the German language to other regions (where the situation is, however, quite diverse - interview with M. Dzingel 2014/Prague). Most of the discussions, conferences, cultural gatherings, and workshops held by the Assembly proceed in German. To name a few examples representing the abundance of concrete projects, there are international summer camps that have been co-organized since 2014 for young people from Germany and for the German minorities of Central, Eastern, and Southeast European countries (Landesversammlung 2018); the project entitled, German Dialects in Czechia, seeks to record German dialects on videos with speakers in different regions (Landesversammlung 2015); and finally, to promote knowledge of standard German, the LandesEcho magazine has recently introduced a "linguistic section" in which readers can exercise their German grammar (LandesEcho 2018: 23).

\section{The language situation from the perspective of representatives of German minority associations}

There are currently 22 regional associations of the German minority. Evidence of the exact membership is lacking, but statistics provided by the minority account for $-4,000$ members in total. The different associations are located in the regions where the German minority has been the most active. Among the most numerous are the Association of Germans in the Cheb Region (Svaz Nèmcú - Region Chebsko) and the Association of Germans in the Ore Mountains Region at Chomutov (Svaz Němcü - Region Krušné Hory a jejich podhirí). The regional distribution of the associations is also interesting: nine are located in Bohemia, five in Moravia, and seven in Silesia (interestingly, the German minority population of Silesia is very small). All these associations are members to the Assembly, which operates as an umbrella organization. Apart from the Assembly, there is the Association of Germans and Friends of German Culture (Spolek Némcí a prátel nèmecké kultury), formerly the Cultural Association of Citizens of German Nationality (Kulturni sdruženi občanů némecké národnosti), which was established during the Prague Spring 
of 1968 and has traditionally been active alongside the country's border with Saxony. Nowadays, the minority associations primarily function as social clubs for the oldest generation, which is partially a result of the minority's extreme demographic aging: according to the latest census of 2011, only $2.5 \%$ of Germans are younger than 14 years, while $46.6 \%$ are aged $>65$ years (ČSÚ 2014: 12).

In our short questionnaire survey of October 2017, we asked the following questions of representatives of the Assembly's regional associations:

- How do you evaluate the state of German instruction in your association and in the region of your activity?

- How do you estimate the future of German as a mother tongue?

- How is the command of German changing from one generation of the minority to another?

These open-ended questions were sent to representatives of the associations, and a $100 \%$ response rate was achieved. The very answers, which were mostly written in German (about one-fifth was written in Czech) revealed, exceptions aside, important grammar errors and the fact that respondents formulated German sentences using Czech syntax. This, too, is a clear sign of language assimilation. An overwhelming majority of the respondents thematize German as a foreign language, emphasizing that for the young generation, it is not an attractive language to learn as a foreign language. This is also attested by the lack of both intergenerational transfer and German communication among family members, as determined in the context of the GIDS and LVE models. The respondents strongly criticized the influence of English, which they believe has been "oppressive" of the German language. Accordingly, some recommend improving the image of German, something the associations themselves should participate in. However, the capacity of associations themselves to do this is questionable, considering their age or educational structure. Long-term and continuous external help is essential, especially from the relatively active German cultural institutions such as the Goethe-Institut.

The responses collected can be divided into two main groups. The first group consists of answers from associations alongside the German or Austrian border. Here, the respondents appreciate German instruction at schools, as in the case of Liberec in North Bohemia. The associations strive to gain from the existence of bilingual education. However, they themselves do little to stimulate the demand for German instruction, which is rather a pragmatic result of the geographical closeness of Germany and the related job opportunities. In spite of that, there are synergies between German instruction 
and the associations' activities, for instance, ties between local teachers and the associations. For example, German teachers (whether or not association members) have been involved in teaching German courses or cultivating various written communications of the associations' representatives.

The associations alongside the border with Germany are generally inclined to believe that German learners are motivated by the perspective of getting better jobs in German companies that operate in the Czech Republic. The following account serves as an example: "As a result of strong post-war assimilation in the Pilsen area, when many Germans relocated to communities that were predominantly Czech, the German language was slowly forgotten by almost everyone. Recently, more and more people have been studying German - I see this as an opportunity for better work in German businesses that have come to Pilsen and other areas." Thus, the economic attractiveness of German is considered as one of the key factors of motivation to learn the language, especially among the young generation, which is perceived by some respondents as "our hope". Conversely, respondents from associations distant from the German border provide another group of accounts, problematizing the distance from the German/Austrian border, which they think is associated with a much weaker role of German in school instruction, and the difficulty in motivating young people to learn German. These opinions are often voiced in the Moravian and Silesian associations, especially rural ones, where the respondents state that they have been unable to motivate young people to learn German. This can be exemplified by the following answer: "Older members of our association are gradually dying out. Young people are not interested in German, pursue other goals, and find it practically irrelevant to promote the language. They are not interested in the language, the association, or our activities." On the other hand, it is necessary to mention that some associations from these regions are very active (in some cases, even more active than some associations in the Czech-German border area - interview with M. Dzingel 2014/Prague). For example, the German minority has its own radio broadcasting in Hlucinsko.

In general, the answers reveal concerns about the future of German not only as mother tongue (indeed, this aspect was rarely mentioned) but, more importantly, as a foreign language in school instruction. Even the Liberec respondent, who evaluated the local situation in the least critical terms, believed that there is a risk that after graduating from their German secondary school, many young people will continue their studies outside the city and the region, thus failing to help preserve German as the language of communication within the minority. Only a fraction of the respondents 
mentioned the necessity to transfer the command of German within the family; only the labor market advantages are mentioned as a motive for learning German. Thus, the German language is not approached as one's mother tongue but instead as a foreign language. While emphasizing the economic advantages of the German language, they ascribe rather marginal importance to the family as an agent of linguistic transmission. By doing so, the minority representatives attest to the state of assimilation in the ethnic group that we have illustrated previously using statistics and research studies (see, e.g., Nekvapil 2001).

However, this skepticism does not correspond with the opinions of the Assembly's main representatives and their efforts to revitalize German as a minority language. The contradiction can be interpreted in different ways. Representatives are supposed to promote a positive, optimistic spirit, which is how they can achieve what they aim for. Moreover, the relatively young age of the Assembly's leadership, compared to the average member, is another source of divergent views on the revitalization effort. On the other hand, however, they realize how complicated the different revitalization plans and projects are to push through, considering the group's strong assimilation and territorial dispersion: "Instruction in our mother tongue was made impossible after 1945, until practically the present day: first for political reasons and then, after 1989, due to prevailing prejudice and taboo surrounding Sudeten German issues. Although the Act on the Rights of Members of National Minorities was adopted in 2001, covering school education, we have been unable to reach the threshold due to the minority's dispersion and mainly due to its assimilation. The result is total Czechization and elimination of identity among the descendants of Germans. For these reasons, the German minority is relatively strongly weakened, and this is why it needs government help" (interview with M. Dzingel 2017/Prague). They recommend establishing bilingual primary schools with German language irrespective of the child's nationality or providing extended language instruction at primary schools in areas with larger numbers of young residents of German descent. They would also appreciate government support for German language in preschool education. Furthermore, the German minority representatives also strive to introduce German as the first foreign language at primary schools where parents and children are interested. Considering the current trend of promoting English as the first foreign language, that language is also typically offered to children from Czech-German families. Minority representatives have traditionally criticized a recommendation by the Ministry of Education to schools to prefer English, as formulated in the official Framework Educational Programmes ("relationship between English and another foreign language"). This 
recommendation is viewed as discriminatory because any parents who might be interested in a foreign language other than English are not guaranteed continuity of instruction at subsequent schools, a fact about which schools are obliged to inform every parent. The decline of interest in German instruction since the 1990s has been the result of such institutionalized "demotivating" from choosing a foreign language other than English (interview with M. Dzingel 2017/Prague). This is an apparent and long-term trend. Moreover, the attractiveness of German is certainly hampered by the relatively low success rate in school-leaving examinations (Bůnová 2018). In order to promote change in this respect, the Assembly established a special committee in 2017 (interview with M. Dzingel 2017/Prague, also Kreisslová 2018: 68-69). However, it is too early to evaluate its performance: no concrete goals have been formulated or activities scheduled yet to achieve a satisfactory solution of the language situation of the German minority.

\section{Conclusion}

The paper corroborates and details some facts that have been debated for the past several years. The minority is not doing well in terms of both sociodemographic situation and perceptions of German as mother tongue. Whether the LVE model or Fishman's GIDS are applied to the current state of German as a minority language, the result is the same: the language finds itself at the highest stage of danger. Fundamental causes of this state include the above-mentioned sociodemographic problems, dispersed settlement structure, and little involvement of the middle and young generations in the life of German associations. Even when German language enjoys a great economic potential in the Czech Republic, it is becoming less popular also due to the global widespread preference of English as the new lingua franca.

Whereas German as a foreign language has its clear place in the Czech Republic, primarily in the context of economic opportunities and the vicinity of German-speaking countries, German as a minority language is declining. The regional specifics are vanishing, with the number of individuals actively speaking the different regional dialects in the order of ones and all of them in the oldest generation. Revitalization of the minority language thus must primarily rely on standard German, which provides more opportunities and encompasses a broader spectrum of communication domains.

To Fishman (1991), intergenerational transmission of language appears as the key to reversing the language shift. However, German is only sporadically transferred from generation to generation in its authentic spoken form, including regionalisms. This was also confirmed by the results of our survey 
among representatives of the regional minority chapters of the Assembly of German Associations in the Czech Republic. There is evidence of absent intergenerational transfer and communication within the family. In spite of this scenario, we are certain that the value of German as a source of shared identity is realized at least by the minority's elites, who are striving to preserve and promote the language - and this is also what makes the revitalization effort meaningful. Therefore, first and foremost, it is necessary to convince members of the minority and their children about the importance and attractiveness of the German language. German associations in the country themselves should be the main promoters of the German language. They should also play a role in promoting and preserving German culture and strengthening people's identification with German as the language of their predecessors. Such actions toward the ethnic group must rely on clearly defined goals and plans to change the language situation (in collaboration with other institutions and experts). The proposals brought forward by the umbrella Assembly, such as establishing bilingual primary schools with German language irrespective of child's nationality or extending language instruction at primary schools in areas inhabited by larger German populations, can definitely make a positive difference in this development. Similarly, their criticism of the ministerial recommendation to prefer English as the first foreign language at primary and secondary schools is justified.

However, the German minority in the Czech Republic cannot rely exclusively on family as the main agent of successful revitalization, since language transmission in the family is such a rare process these days (as demonstrated above) and an overwhelming majority of families would have to be start the process intentionally "from scratch". Externally oriented actions are also needed, such as promoting the German language and explaining the cultural, economic, and cognitive advantages of bi- or multilingualism in the mainstream society. At the same time, one must strive to push through changes in the Czech Republic's educational and linguistic culture. The minority should continue and strengthen its role as mediator of those different activities to promote German instruction that have been undertaken by German institutions such as the Goethe-Institut. Such activities should be primarily promoted in borderline regions with the largest populations of Czech Germans and their children.

\section{References}

Aussiedlerbeauftragter. 2017. Rede Bundesbeauftragter Koschyk trifft deutsche Minderheit in der Tschechischen Republik [Speech of the Federal Commissioner Koschyk On the German Minority in the Czech Republic] Online https:/www.aussiedlerbeauftragter.de/ 


\section{Sandra Kreisslová, Lukáš Novotný, Between Language Revitalization and Assimilation}

SharedDocs/Reden/AUSB/DE/koschyk-botschaft-prag-minderheitenvertreter.html. Accessed June 8, 2018.

Bůová, Michaela. 2018. Němčinářky: Letošní maturitní test byl neúměrně těžký, žáky demotivoval. [German Language Teachers: This Years' Graduation Test Was Extremely Difficult, Demotivating Pupils]. iDnes.cz. Online https://zpravy.idnes.cz/statni-maturita-nemcinastudenti-neuspeli-f2t-/domaci.aspx?c=A180601_114743_domaci_nub. Accessed June 8, 2018.

ČSÚ. 2014. Národnostni struktura obyvatel. [National Population Structure]. Praha: ČSÚ. Online https://www.czso.cz/documents/10180/20551765/170223-14.pdf. Accessed March 1, 2018.

McDermott, Philip. 2016. "Language rights and the Council of Europe: A failed response to a multilingual continent?" Ethnicities 17 (5): 603-626.

Dovalil, Vít. 2013. Jazykové právo - konceptuální perspektivy a metodologie jeho zkoumání. In Gladkova, Hana and Kina Vačkova (eds.). Jazykové právo a slovanské jazyky. Praha: Filozofická fakulta: 13-30.

Dvořák, Tomáš. 2013. Vnitřni odsun 1947-1953: závèrečná fáze “očisty pohraničí v politických a společenských souvislostech poválečného Československa. Brno: Matice moravská.

European Parliament. 2017. Language policy. Brussels: European Parliament. Online http:// www.europarl.europa.eu/atyourservice/en/displayFtu.html?ftuId=FTU_3.6.6.html. Accessed June 7, 2018.

Fairclough, Norman. 2003. "Political Correctness: the Politics of Culture and Language". Discourse \& Society 14 (1): 17-28.

Fishman, Joshua. 1991. Reversing Language Shift: theoretical and empirical foundations of assistance to threatened languages. Clevedon: Multilingual Matters.

Goethe-Institut. 2012. Šprechtíme [We Speak German]. Online http://www.goethe.de/ins/ cz/prj/jug/spr/udp/cs8128950.htm. Accessed June 7, 2018.

Houžvička, Václav. 2015. Czechs and Germans 1848-2004: The Sudeten Question and the Transformation of Central Europe. Praha: Karolinum.

Kreisslová, Sandra. 2013. Konstrukce etnické identity a kolektivni pamèti v biografických vyprávèních českých Nèmcü: na př́kladu vzpominek Nëmců na Chomutovsku [Construction of the Ethnic Identity and Collective Memory in Biographical Narrations of Czech Germans: On the Example of the Memories of the Germans in the Chomutov Region]. Praha: Univerzita Karlova v Praze, Filozofická fakulta.

Kreisslová, Sandra and Novotný, Lukáš. 2015. Kulturní rozmèr činnosti německé menšiny [The cultural Dimension of Activities of the German Minority]. Praha: Univerzita Karlova, Právnická fakulta.

Kreisslová, Sandra. 2018. Německá menšina v českých zemích od roku 1945 až po současnost [German Minority in the Czech Lands from 1945 to the Present]. In Svoboda, Tomáš, Kreisslová, Sandra, Vodrážsková, Lenka and Vodrážka Daniel. Projekt "Němčina jako menšinový jazyk v ČR”. Úřad vlády České republiky: 40-69.

Kuklík, Jan and René Petráš. 2017. Minorities and Law in Czechoslovakia 1918-1992. Praha: Karolinum.

LandesEcho 5 (5), 2018: 23. 


\section{Journal of Nationalism, Memory \& Language Politics 12(1)}

Landesversammlung. 2012. Die Willenserklärung des Präsidiums der Landesversammlung. Online [The Declaration of Intent by the Presidium of the National Assembly]. On-line http://www.landesversammlung.cz/de/ueber-uns/willenserkl\%C3\%A4rung-der-lv. Accessed June 6, 2018.

Landesversammlung. 2015. Mundart [Dialect]. http://www.landesversammlung.cz/de/projekte/mundart. Accessed June 7, 2018.

Landesversammlung. 2018. Sommercamp 2018 [Summer Camp]. Online: http://www. landesversammlung.cz/de/neuigkeiten/lv-aktuell/274-letn\%C3\%AD-kemp-2018. Accessed June 7, 2018.

Moseley, Christopher (ed.). 2010. Atlas of the World's Languages in Danger. Paris: UNESCO Publishing. Online www.unesco.org/culture/en/endangeredlanguages/atlas. Accessed May 13, 2018.

Nekvapil, Jiří. 2001. "Jazykové biografie a analýza jazykových situací: k osudům německé komunity v České republice [Language Biography and Analysis of Language Situations: Regarding the Fate of the German Community in the Czech Republic]". Casopis pro moderni filologii 83 (2): 65-80.

Nekvapil, Jiří and Marek Nekula. 2006. On Language Management in Multinational Companies in the Czech Republic. Current Issues in Language Planning 7 (2-3): 307-327.

Nekvapil, Jiří. 2010. "O historii, teorii a modelech jazykového plánování” [On History, Theory and Models of Language Planning]. Slovo a slovesnost 71, (1): 53-73.

Neústupný, Jiř́. 2002. "Sociolingvistika a jazykový management [Sociolinguistics and Language Management]”. Sociologický ćasopis 38 (4): 429-442.

Neustupný, Jiří and Jiří Nekvapil. 2003. Language Management in the Czech Republic. Current Issues in Language Planning 4 (3-4): 181-366.

Novotný, Lukáš. 2013. “Aktuální problémy německé menšiny ve 21. století” [Current Problems of the German Minority in the 21st Century]. Acta Universitatis Carolinae - Iuridica 6 (1): 83-93.

Novotný, Lukáš. 2015a. "German Language and German Minority". The Annual of Language \& Politics and Politics of Identity 9 (1): 23-42.

Novotný Lukáš. 2015b. "Německo a německá menšina” [Germany and German Minority]. Acta Universitatis Carolinae - Iuridica, 4: 135-145.

Novotný, Lukáš. 2016. "Die deutsche Minderheit und ihre Presse" [German Minority and Ist Press]. Aussiger Beiträge 16: 145-158.

Petráš, René. 2007. Menšiny v komunistickém Československu [Minorities in Communist Czechoslovakia]. Praha: VIP Books.

Sandovici, Maria Elena and Ola Listhaug. 2009. "Ethnic and Linguistic Minorities and Political Participation in Europe." International Journal of Comparative Sociology 51 (1-2): 111136.

Šatava, Leoš. 2009. Jazyk a identity etnických menšin: možnosti zachování a revitalizace [Language and Identity of Ethnic Minorities: Possibilities of Conservation and Revitalization]. Praha: SLON.

Spolsky, Bernard. 1998. Sociolinguistics. Oxford: Oxford University Press. 
Sandra Kreisslová, Lukáš Novotný, Between Language Revitalization and Assimilation

Spurný, Matěj. 2011. Nejsou jako my. Česká společnost a menšiny v pohraničí (1945-1960) [They Are Not Like Us. Czech Society and Minorities in Borderlands]. Praha: Antikomplex.

Staněk, Tomáš. 1993. Německá menšina v českých zemích 1948-1989 [German Minority in the Czech lands 1948-1989]. Praha: Institut pro středoevropskou kulturu a politiku.

Togeby, Lise. 2008. “The Political Representation of Ethnic Minorities. Denmark as a Deviant Case". Party Politics 14 (3): 325-343.

Unesco.org. 2003. Language Vitality and Endangerment. Paris: UNESCO. Online http:// www.unesco.org/new/fileadmin/MULTIMEDIA/HQ/CLT/pdf/Language_vitality_and_ endangerment_EN.pdf. Accessed March 2, 2018.

Weinreich, Uriel. 1968. Languages in contact. Findings and problems. New York: Mouton \& Co.

Williams, Glyn. 2007. "Reversing language shift - a sociological visit". In Darquennes, Jeroen (ed.). Contact Linguistics and Language Minorities/Kontaktlinguistik und Sprachminderheiten/Linguistique de Contact et Minorités Linguistiques. Augustin: Asgard, 161-177. 